\title{
Impact of Monetary Instrument Shock Against Inflation in North Sumatra:

\author{
Two-Stage Least Square Method
}

Nelly Hutajulu, Fitrawaty, and Muhammad Fitri Rahmadana

\{nellyhutajulu@yahoo.co.id\}

Department of Economics, Faculty of Economics, State University of Medan, North Sumatra, 20219, Indonesia

\begin{abstract}
The study explores the relationship among inflation and economic growth in North Sumatra. Two-Stage Least Square (2SLS) technique is used to analyze the impact of monetary instrument shock against inflation the period of 1994-2017. The result of research concludes that economic growth effect significantly to inflation in North Sumatra and positive direction. The amount of money in circulation, the money supply previous period a significant and negative effect against inflation in North Sumatra. interest rate of Bank Indonesia, unemployment is a significant and positive effect against inflation in North Sumatra. Inflation has no effect on against the economic growth of North Sumatra. The amount of money in circulation, a significant and positive effect toward economic growth in North Sumatra. While the money supply previous period does not affect economic growth in North Sumatra.
\end{abstract}

Keywords: Inflation, Gross Domestic Product (GDP), Money Supply, Interest Rate of Bank Indonesia, Exchange Rate, Unemployment, Two-Stage Least Square (2SLS)

\section{Introduction}

Inflation is an economic phenomenon that is very interesting to be discussed especially with regard to their impact on the stability of the economy of North Sumatra. The growth and stability of the economy can be said to constitute problems of each country or region, including North Sumatra. There is a lot of effort through a variety of policies have been applied in order to improve or at least maintain the stability of the economy that is expected to be able to provide prosperity for the community-wide. One such business is through the control of inflation rate.

The inflation rate is determined by the forces of supply and demand for goods and services that reflect the behavior of the market or the public. Fluctuations in the overall economy emanating from changes in aggregate demand or aggregate deals. Economists refer to changes in supply and demand as aggregate shocks to the economy. Shocks on the domestic monetary variables can be any change of policy by the monetary authorities, such as the monetary policy is expansionary which can have an effect on the incidence of money supply shock and interest rate shock. The existence of a shock on the monetary variables directly or indirectly influence aggregate demand and further towards the output.

North Sumatra which meets the criteria of small and open economy, causing any external shock occurring in the world economy will affect the economy in North Sumatra. The presence of shocks in a monetary variable can be either a foreign exchange rate of change of the exchange rate system that embraced as well as the movement of exchange rates of foreign currency against domestic. Shocks in exchange rates could be caused by the growth of the money supply thus causing high inflation, a consequence of high inflation is the currency will 
depreciate (Mankiw, 2007).

Based on the data of inflation in North Sumatra years 1994-2017 the rate of inflation in North Sumatra indicates that the fluctuation from year to year. The highest inflation in 1998 reached level 83.56 percent. On the other hand, the movement of inflation decreased by 1.37 percent in 1999. In addition, with raised the price of fuel oil in 2002, 2005, 2008, and 2013, also became a contributor to inflation was high enough in the year. Inflation in the year 2002 (9.59\%), year 2005 (22.41 percent), year 2008 (10.72\%), and in 2013 (10.18 percent). The 2016 year inflation exceeds the target set by Bank Indonesia at the beginning of the year that is 6.34 percent and also speeding the Government's inflation target of 5.3 percent. While the year 2017 the inflation rate decreased by 3.20 percent.

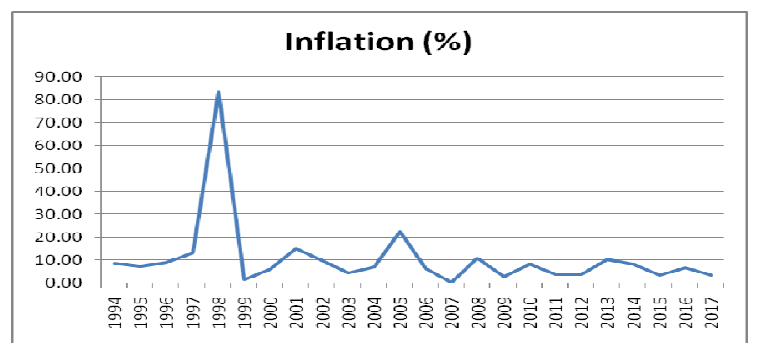

Figure 1: The rate of Inflation in North Sumatra Years 1994-2017

Review of previous research that the factors that influence the formation of inflation in many countries, including Indonesia, comes from domestic and external variables are variables. These variables include gross domestic product, currency exchange rates, interest rates, money supply, and change or economic shocks in other countries (Sipayung and Budhi, 2013).

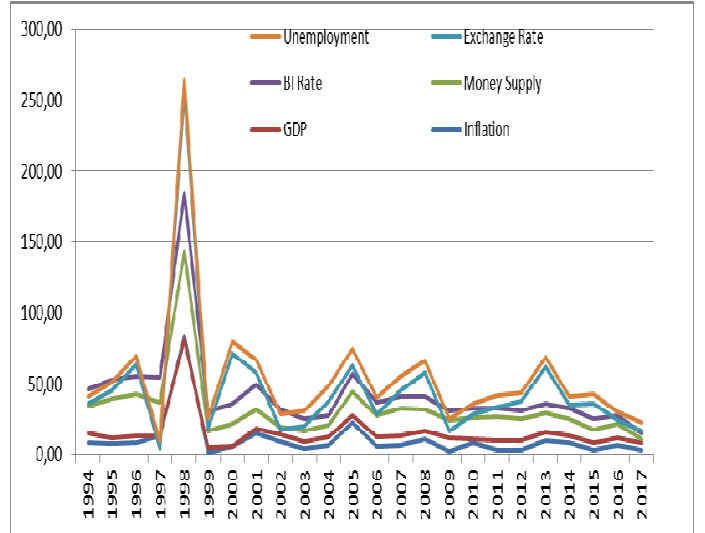

Figure 2: The movement of the inflation and macroeconomic variables in North Sumatra: 1994-2017.

Based on Figure 2 shows that in 2005 the inflation rate up from 6.80 percent to 22.41 percent, the inflation rate increased dramatically. While the growth of the gross domestic product (GDP) decreased by 5.48 percent and the unemployment rate in North Sumatra of 11.90 percent increase compared to the previous period. This is due to the increasing administered price of fuel oil that has an impact on the economy. To suppress such high 
inflation the Bank Indonesia took the policy by lowering interest rates, but in the same year, the Bank Indonesia interest rate (BI Rate) experienced an increase of 7.30 percent to 12.83 percent. The year of 2009 the amount of money in circulation increased from 1,895,839 billion rupiahs into 2,141,384 billion rupiahs. And in 2009 the rupiah depreciates from Rp 10,950 per dollar to Rp 9,400 per dollar, which with increasing money supply in the community and the occurrence of the depreciation of the rupiah should have an impact on high inflation, but that happened exactly the opposite where is the inflation in 2009 experienced a decrease of 10.72 percent to 2.61 percent.

The unemployment rate in 2009 decreased by 8.45 percent compared to the previous period. This data does not match the theory. The phenomenon certainly became one of appeal to conduct research related to inflation. In addition, with the discovery of the difference results from previous studies in which the existence of the results corresponding to the theory and the existence of conflicting results with theory. This fact certainly questions about how much influence the gross domestic product (GDP), the money supply, interest rates, exchange rates and the rate of unemployment in increasing the inflation rate and push in North Sumatra.

The purpose of this research is to know the influence of monetary instrument that simultaneously affect inflation and gross domestic product (GDP) in North Sumatra.

\section{Conceptual Framework}

\subsection{Theoretical Framework}

According to the theory of Keynes explained that the aggregate demand curve is sloped downhill, because of the lower price level (Ps $\downarrow$ ), with a constant nominal amount of money, causing the number of real money in terms of goods and services that can be purchased $(\mathrm{M} / \mathrm{P} \uparrow)$ an increasingly large. The greater the amount of money in the real sense $(\mathrm{M} / \mathrm{P} \uparrow)$ produced and the price level of yan is getting lower interest rates to cause a decrease $(r \downarrow)$ ). The investment cost is cheap to buy new physical capital to make investments in more profitable and stimulate investment expenditures planned. Because of the increase in investment expenditure is planned to directly add to aggregate demand (Yad), the lower price level results in the level of an aggregate output of the requested amount ware higher $(\mathrm{P} \uparrow \rightarrow \mathrm{Y} \alpha \mathrm{d} \downarrow)$, systematically, the equation can be written as follows:

$$
\mathbf{P} \uparrow \rightarrow \mathbf{M} / \mathbf{P} \uparrow \rightarrow \mathbf{r} \downarrow \mathbf{Y a d} \uparrow
$$

Other mechanisms that generate aggregate demand curve is sloped downward operating through foreign trade. Due to lower price levels, resulting in the amount of money in the real sense of the larger and lower interest rates. This led to a decline in the value of the assets of the dollar relative to other currencies. The dollar value of the lower domestic goods made relatively be cheaper against foreign goods, this led to net exports increase aggregate demand (Mankiw, 2007)

As inflation has increased, it will cause a decline in the level of investment. This is due to a rise in inflation will encourage a rise in interest rates, the interest rate increase will result in an investment decline. The fall in investment means lower production capacity. When declining production capacity this will have an impact on decreasing the absorption of labor on the one hand because unemployment is rising at one party then the people's income is reduced, decreasing level people's income in the next impact on the Community consumption decreased. Where is the decrease in the Community consumption also means a decrease in 
aggregate demand (consumption demand), this then leads to the pace of economic growth has decreased and the next will cause budget funds will also participate go down.

When funding for the budget decline but on the other side of the Government wants to maintain a high budget to spur economic growth, then the Government will be trying to find new funding by way of printing money so the amount of money in circulation the more impact on high inflation.

\subsection{Empirical Framework}

Islam et al. (2017) investigated determinants of factors that affecting inflation in Malaysia using a quantitative method and the econometric model is used to identifying the relationship between the dependent and independent variables. The econometric model shows the relationship between the independent variables namely money supply, exchange rate and unemployment rate on inflation, the dependent variable in this model.

Pahlavani and Rahimi (2009) investigated sources of inflation Iran: an application of the ADRL approach using annual time series data from 1971 to 2006. The empirical results show that in the long run, the main determinants of inflation in Iran are the liquidity, exchange rate, the rate of expected inflation and the rate of imported inflation. All these variables had significant effects on the inflation rate in the short run. Moreover, the destructive eight-year war with Iraq had a positive effect on the inflation rate in the Iranian economy. Finally, the error correction term $(-0.3995)$ is found to be negative and statistically significant suggesting a quick adjustment process.

Hossain (2010) investigated the behavior of broad money demand in Bangladesh using annual data over the period of 1973- 2008 by using the Johansen co-integration test and the error correction model. Empirical results suggest the existence of a causal relationship between money supply growth and inflation.

Nazer (2016) investigates the impact of the money supply, oil price, import values, U.S. interest rate, and Saudi Real GDP on Saudi CPI. First we followed the process of testing the credibility of our variables. The Unit Root Test shows that all level variables are nonstationary, however, the first difference shows that all variables are stationary and integrated of order one. Next, we have used Johansen's cointegration test, and we have found that our variables are cointegrated. As a result, we can use the level variables in our estimate. Using a multiple regression model, we found positive statistical evidence between CPI and money supply, and import values, and a negative relation between CPI and real GDP in Saudi Arabia. To carry on our analysis and investigation further, we performed the causality test to confirm one-way causality. The causality tests show that money supply, import values, and oil prices cause Saudi's CPI, but not the other way around.

\section{Research Design}

\subsection{Data}

The research data will be used in this research in the form of secondary data. Secondary data that will be used is the data time series during the year 1994-2017 which is the total amount of data the gross domestic product (Y), the money supply (MS), Bank Indonesia interest rate (r), the exchange rate (EXC), and unemployment (Unemp) against the inflation (INF) in Nort Sumatra. The data can be taken from the Bank Indonesia (BI) and the Central Bureau of 
Statistics (BPS) or via the official website of each of the institutions (www.bi.go.id and www.bps.go.id). This study uses statistics programs help E-Views version 7.

\subsection{Model Design}

The estimation model used in this study is Two Stage Least Square. The model in the research of the dynamic model is adapted from inflation by A.W. Philip describes the relationship of the price level and the stock of money. The Adaptive model Cagan starting from the demand of money in the form of the function eksponesial (Rahardja and Manurung, 2004):

$$
\operatorname{InM}_{\mathrm{t}} / \mathrm{P}_{\mathrm{t}}=\alpha_{0}+\alpha_{1} \operatorname{In}\left(\mathrm{Y}_{\mathrm{t}}\right)+\alpha_{2} \mathrm{R}_{\mathrm{t}}+\mu_{\mathrm{t}} \ldots \ldots \ldots \ldots \ldots \text {. } \ldots \ldots \ldots \text { (3.1) }
$$

Note that the value of $R_{t}=r_{t}+\pi_{t}$ where $r_{t}$ is the real interest rate and the nominal interest rate of substitution $\left(\mathrm{R}_{\mathrm{t}}\right)$ and $\mathrm{r}_{\mathrm{t}}+\pi_{\mathrm{t}}$ will change the model request for money as follows:

$$
\operatorname{InM}_{\mathrm{t}} / \mathrm{P}_{\mathrm{t}}=\alpha_{0}+\alpha_{1} \operatorname{In}\left(\mathrm{Y}_{\mathrm{t}}\right)+\alpha_{2}\left(\mathrm{r}_{\mathrm{t}}+\pi_{\mathrm{t}}\right)+\mu_{\mathrm{t}}
$$

where $\pi_{\mathrm{t}}=$ expectations of inflation, $\lambda=\alpha_{0}+\alpha_{1} \mathrm{Y}_{\mathrm{t}}+\alpha_{2} \mathrm{r}_{\mathrm{t}}$ and $\alpha=\alpha_{2}$

$$
\operatorname{InM}_{\mathrm{t}} / \mathrm{P}_{\mathrm{t}}=\lambda+\alpha \pi_{\mathrm{t}}+\mu_{\mathrm{t}}
$$

For example In $\left(\mathrm{M}_{\mathrm{t}}\right)=\mathrm{m}_{\mathrm{t}}$ and $\mathrm{In}\left(\mathrm{P}_{\mathrm{t}}\right)=\mathrm{p}_{\mathrm{t}}$ so that equation (3.2) changed to

$\mathrm{m}_{\mathrm{t}}-\mathrm{p}_{\mathrm{t}}=\lambda+\alpha \pi_{\mathrm{t}}+\mu_{\mathrm{t}} \ldots \ldots \ldots \ldots \ldots \ldots \ldots \ldots \ldots$ (3.3)

Cagan model explains that expectations of inflation expectations is a change of the price level in the future are

$$
\pi_{\mathrm{t}}-\pi_{\mathrm{t}-1}=\rho\left(\Delta \mathrm{p}_{\mathrm{t}}-\pi_{\mathrm{t}-1}\right) 0 \leq \rho \leq 1
$$

If the value of the inflation expectations of the period $(t)$ is the weighted average of the inflation of the previous period:

$$
\pi_{\mathrm{t}}=\rho \Delta \mathrm{p}_{\mathrm{t}}+(1-\rho) \pi_{\mathrm{t}-1}
$$

Substituting equation (3.5) to (3.3) and the results of the substitution of a period of retreat or $(\mathrm{t}-1)$ produces a model of money demand period $(\mathrm{t})$ and $(\mathrm{t}-1)$ :

$\mathrm{m}_{\mathrm{t}}-\mathrm{p}_{\mathrm{t}}=\lambda+\alpha\left(\rho \Delta \mathrm{p}_{\mathrm{t}}+(1-\rho) \pi_{\mathrm{t}-1}+\mu_{\mathrm{t}}\right.$

$\mathrm{m}_{\mathrm{t}-1}-\mathrm{p}_{\mathrm{t}-1}=\lambda+\alpha \pi_{\mathrm{t}-1}+\mu_{\mathrm{t}-1}$

$\pi_{\mathrm{t}-1}=\mathrm{m}_{\mathrm{t}-1}-\mathrm{p}_{\mathrm{t}-1}-\lambda-\mu_{\mathrm{t}-1 / \alpha}$.

Substituting equation (3.6) to (3.7) will generate inflation model as follows:

where $\lambda=\alpha_{0}+\alpha_{1} Y_{t}+\alpha_{2} r_{t}$

$$
\mathrm{p}_{\mathrm{t}}=\rho \lambda+\alpha \rho \Delta \mathrm{p}_{\mathrm{t}}+\mathrm{m}_{\mathrm{t}}+(1-\rho)\left(\mathrm{m}_{\mathrm{t}-1}-\mathrm{p}_{\mathrm{t}-1}\right)+\varepsilon_{\mathrm{t}}
$$

$\mathrm{p}_{\mathrm{t}}=\rho\left(\alpha_{0}+\alpha_{1} \mathrm{Y}_{\mathrm{t}}+\alpha_{2} \mathrm{r}_{\mathrm{t}}\right)+\alpha \rho \Delta \mathrm{p}_{\mathrm{t}}+\mathrm{m}_{\mathrm{t}}+(1-\rho)$

$\left(\mathrm{m}_{\mathrm{t}-1}-\mathrm{p}_{\mathrm{t}-1}\right)+\varepsilon_{\mathrm{t}}$

$p_{t}=\alpha_{0} \rho+\alpha_{1} \rho Y_{t}+\alpha_{2} \rho r_{t}+\alpha \rho \Delta p_{t}+m_{t}+(1-\rho)$

$\left(\mathrm{m}_{\mathrm{t}-1}-\mathrm{p}_{\mathrm{t}-1}\right)+\varepsilon_{\mathrm{t}}$

The Philips curve describes the relationship between changes in the levels of wages with unemployment levels. If $\mathrm{w}_{\mathrm{t}}=\ln \left(\mathrm{w}_{\mathrm{t}}\right)$ is equal to the rate of price change $\left(\Delta \mathrm{p}_{\mathrm{t}}\right)$ or inflation that is: $\Delta \mathrm{w}_{\mathrm{t}}=\Delta \mathrm{p}_{\mathrm{t}}=\mathrm{f}\left(\right.$ Unemp $\left._{\mathrm{t}}\right)$. By entering variables into the equation unemployment (3.8) will then be retrieved equations (3.9)

$$
\begin{aligned}
& \mathrm{P}_{\mathrm{t}}=\alpha_{0} \rho+\alpha_{1} \rho \mathrm{Y}_{\mathrm{t}}+\alpha_{2} \rho \mathrm{r}_{\mathrm{t}}+\alpha_{3} \rho \text { Uunemp }_{\mathrm{t}}+\alpha_{4} \mathrm{MS}_{\mathrm{t}}+ \\
& \alpha_{5}(1-\rho) \mathrm{MS}_{\mathrm{t}-1}+\alpha_{6}(1-\rho) \mathrm{P}_{\mathrm{t}-1}+\varepsilon_{\mathrm{t}} \\
& \text { where: } \\
& \mathrm{b}_{0}=\alpha_{0} \rho \quad \mathrm{b}_{3}=\alpha_{3} \rho \text { Unemp }_{\mathrm{t}} \\
& \mathrm{b}_{1}=\alpha_{1} \rho \mathrm{Y}_{\mathrm{t}} \quad \mathrm{b}_{4}=\alpha_{4} \rho \mathrm{MS}_{\mathrm{t}} \\
& \mathrm{b}_{2}=\alpha_{2} \rho \mathrm{r}_{\mathrm{t}} \quad \mathrm{b}_{5}=\alpha_{5}(1-\rho) \mathrm{MS}_{\mathrm{t}-1} \\
& \mathrm{~b}_{6}=\alpha_{6}(1-\rho) \mathrm{P}_{\mathrm{t}}
\end{aligned}
$$

\section{Inflation model as follows:}


$\begin{aligned} \pi_{\mathrm{t}}(\mathrm{AS})= & \mathrm{b}_{0}+\mathrm{b}_{1} \mathrm{Y}_{\mathrm{t}}+\mathrm{b}_{2} \mathrm{MS}_{\mathrm{t}}+\mathrm{b}_{3} \mathrm{MS}_{\mathrm{t}-1}+\mathrm{b}_{4} \mathrm{r}_{\mathrm{t}}+\mathrm{b}_{5} \\ & \text { Unemp }_{\mathrm{t}}+\mathrm{b}_{6} \pi_{\mathrm{t}-1}+\varepsilon_{1 \mathrm{t}} \ldots \ldots \ldots \ldots \ldots \ldots \ldots \ldots \ldots \ldots \ldots \ldots \ldots \ldots \ldots \ldots \ldots\end{aligned}$

North Sumatra which meets the criteria of a small and open economy. Then the model used Mundell Fleming. Mundell Fleming showing the effects of economic policy on an open economy dependent on the exchange rate system. Indonesia has a free floating-exchange-rate. This model is that the fiscal policy does not affect the aggregate income on the free-floating exchange rate. Fiscal expansion causes currency increases, lowering the net export and against the aggregate income (Mankiw, 2007)

$\mathrm{NX}(\mathrm{ER})=\mathrm{Y}-\mathrm{C}(\mathrm{Y})-\mathrm{I}(\mathrm{r})-\mathrm{G}$

where:

NX(EXC): Exchange Rate (Rupiah/US\$)

Y: GDP (Billion Rupiah)

$\mathrm{C}=$ function $(\mathrm{Y})$

$\mathrm{I}=$ function $(\mathrm{r}): \mathrm{BI}$ Rate $(\%)$

$\mathrm{G}=0$

Substituting equation (3.9) to (3.10) will generate the GDP model as follows:

$\mathrm{NX}(\mathrm{EXC})_{\mathrm{t}}=\mathrm{Y}_{\mathrm{t}}-\mathrm{Y}_{\mathrm{t}}-\left(\mathrm{b}_{0}+\mathrm{b}_{1} \mathrm{Y}_{\mathrm{t}}+\mathrm{b}_{2} \mathrm{r}_{\mathrm{t}}+\mathrm{b}_{3}\right.$ Unemp $_{\mathrm{t}}$

$\left.+\mathrm{b}_{4} \mathrm{MS}_{\mathrm{t}}+\mathrm{b}_{5} \mathrm{MS}_{\mathrm{t}-1}+\mathrm{b}_{6} \pi_{\mathrm{t}}+\varepsilon_{1 \mathrm{t}}\right)-\mathrm{r}_{\mathrm{t}}-0$

GDP model as follows:

$\mathrm{Y}_{\mathrm{t}}(\mathrm{AD})=\alpha_{0}+\alpha_{1} \pi_{\mathrm{t}}+\alpha_{2} \mathrm{MS}_{\mathrm{t}}+\alpha_{3} \mathrm{MS}_{\mathrm{t}-1}+\alpha_{4} \mathrm{EXC}_{\mathrm{t}}+$ $\alpha_{5}$ Unemp $_{\mathrm{t}}+\alpha_{6} \mathrm{Y}_{\mathrm{t}-1}+\varepsilon_{2 \mathrm{t}}$

The next test of the identification with the order condition in this study are:

$\pi_{\mathrm{t}}=(\mathrm{K}-\mathrm{k})>(\mathrm{m}-1)=7-5>2-1$ (Over Identified)

$\mathrm{GDP}_{\mathrm{t}}=(\mathrm{K}-\mathrm{k})>(\mathrm{m}-1)=7-5>2-1$ (Over Identified $)$

The process reduces the form carried out to know the exogenous variables in the system of simultaneous equations. As for the form of the reduced form is:

$\Pi_{15} \mathrm{UN}+\Pi_{16} \pi_{\mathrm{t}-1}+\Pi_{17} \varepsilon_{1 \mathrm{t}}$

$$
\pi_{\mathrm{t}}=\Pi_{10}+\Pi_{11} \mathrm{Y}_{\mathrm{t}}+\Pi_{12} \mathrm{MS}_{\mathrm{t}}+\Pi_{13} \mathrm{MS}_{\mathrm{t}-1}+\Pi_{14} \mathrm{r}_{\mathrm{t}}+
$$

$+\Pi_{25} \mathrm{UN}_{\mathrm{t}}+\Pi_{26} \mathrm{Y}_{\mathrm{t}-1}+\Pi_{27} \varepsilon_{2 \mathrm{t}}$

where:

$\pi_{\mathrm{t}}=$ Inflation $(\%)$

$\mathrm{Y}_{\mathrm{t}}=$ GDP (Billion Rupiah)

$r_{t}=$ BI Rate $(\%)$

$\mathrm{UN}_{\mathrm{t}}=$ Unemployment $(\%)$

$\mathrm{MS}_{\mathrm{t}}=$ Money Supply (Billion Rupiah)

$\mathrm{ER}_{\mathrm{t}}=$ Exchange Rate (Rupiah/Dollar)

\section{Results And Discussion}

\subsection{Models of Inflation}

The results of the estimation equation of inflation in this research are: 


$$
\begin{array}{r}
\pi_{\mathrm{t}}=-95.46891+9.436628 \mathrm{Y}_{\mathrm{t}}-2.344563 \mathrm{MS}_{\mathrm{t}}- \\
0.440800 \mathrm{MS}_{\mathrm{t}-1}+3.002132 \mathrm{r}_{\mathrm{t}}+2.731551 \mathrm{UN}_{\mathrm{t}} \\
-0.604866 \pi_{\mathrm{t}-1}+\varepsilon_{l \mathrm{t}}
\end{array}
$$

Estimation model of simultaneous inflation $\left(\pi_{\mathrm{t}}\right)$ in North Sumatra affected by the amount of money in circulation $\left(\mathrm{MS}_{\mathrm{t}}\right)$, the money supply previous period $\left(\mathrm{MS}_{\mathrm{t}-1}\right)$, the BI Rate $\left(\mathrm{r}_{\mathrm{t}}\right)$, unemployment $\left(\mathrm{UN}_{\mathrm{t}}\right)$, inflation of the previous period $\left(\pi_{\mathrm{t}-1}\right)$ and economic growth $\left(\mathrm{Y}_{\mathrm{t}}\right)$.

The results showed that economic growth was a positive and significant effect against inflation in North Sumatra. When the economy is on the rise then inflation will also increase, and when the economy is declining then inflation will also be down. This is caused by the economy's high growth accompanied by productivity without adequate so that increased demand could not be met in terms of bidding that triggers the onset of inflation. This is in accordance with Keynesian Theory (Wisda Nugroho and Umar Basuki, 2012) which stated that the increase in expenditure side of GDP will increase the effective demand of society. When the number of requests is effective against commodity price levels to increase, in effect, exceeding the maximum number of goods that can be produced by the community, then the inflationary gap would arise and cause problems for inflation.

The amount of money in circulation, the money supply previous period there was a significant and negative effect against inflation in North Sumatra. This is in accordance with the research conducted by (Wisda Nugroho and Umar Basuki, 2012) stating that a variable amount of money supply (M2) a negative and significant effect against inflation. This is because of the money supply in the broad sense of the money supply, money giral, and quasimoney. Quasi-money percentage allegedly comprising fixed deposits, savings, and foreign currency accounts of a private domestic property is big enough. Quasi-money in this instance is a value that is not liquid. So even though the value is high but not enough to affect the existing inflation increase in economic growth.

Bank Indonesia interest rate has a significant and positive influence against inflation in North Sumatra. The increase in Bank Indonesia interest rate will lower inflation. The decline in inflation was caused because society puts more motivated in the bank in the form of deposits or in the form of savings because they expect favorable returns. Therefore the increase in Bank Indonesia interest rate will be followed by a decline in the money supply. This will cause a decline in the demand for goods and services caused by the reluctance of the public to buy goods and services for saving money in the bank is more beneficial than spending money. Furthermore, the decline in the demand for goods and services will trigger the price reductions that will bring down inflation. This theory of Fisher (Mankiw, 2007) nominal interest rates have a positive relationship and in line with inflation. This is in accordance with the research conducted by (Pahlavani and Rahimi, 2009) which stated in the long-run, the main determinants of inflation in Iran are the liquidity, exchange rate, the rate of expected inflation and the rate of imported inflation.

But the influence of unemployment against inflation in North Sumatra has a significant and positive influence. This is not in accordance with the theory of the Philips curve (Mankiw, 2007) in the Philips Curve describes the relationship of inflation with the unemployment rate. In the Philips curve shows a negative relationship between changes in the level of wages and the unemployment rate that is when unemployment rises, wage levels are low or vice versa. Based on the descriptive analysis, general inflation in North Sumatra over the past twenty-four years the average was also affected by the monetary crisis, the rising needs of the staple, the increase in the price of fuel, not as a result of the pull request. This results is consistent with the work of (Furuoka, 2007) 


\subsection{Models of Economic Growth (GDP)}

The results of the estimation equation of economic growth (GDP) in this research are:

$\mathrm{Y}_{\mathrm{t}}=8.621557+0.005577 \pi_{\mathrm{t}}+0.463721 \mathrm{MS}_{\mathrm{t}}-$

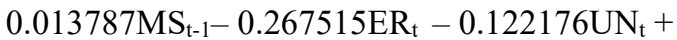

$1.068020 \mathrm{Y}_{\mathrm{t}-1}+\varepsilon_{2 \mathrm{t}}$

Estimation model of simultaneous economic growth (GDP) in North Sumatra affected by the amount of money in circulation $\left(\mathrm{MS}_{\mathrm{t}}\right)$, the money supply previous period $\left(\mathrm{MS}_{\mathrm{t}-1}\right)$, the Exchange Rate $\left(E R_{t}\right)$, unemployment $\left(\mathrm{UN}_{\mathrm{t}}\right)$, inflation $\left(\pi_{\mathrm{t}}\right)$ and economic growth of the previous period $\left(\mathrm{Y}_{\mathrm{t}-1}\right)$.

The results showed that inflation does not affect economic growth in North Sumatra. Low or stable inflation indicated prices are also stable then it will increase the community's ability to acquire goods and services that trigger the production of goods and services will increase. Increased production of goods and services will improve the economy. Rising inflation is not always followed by the declining economy and reverse the fall in inflation is not always followed by a rise in economic growth in North Sumatra. The results of this research are consistent with research done (Amrini, Aimon and Syofyan, 2012) that shows the variables do not affect inflation significantly to a gross domestic product (GDP) but the positive direction.

The money supply has a significant and positive influence toward economic growth. This condition is caused due to increasing the money supply will encourage a rise in domestic demand. This is in accordance with the opinion of (Mishkin, 2015) which States that the higher the output at a certain interest rate, the money supply will be higher. However, the amount of money circulating in the previous period does not affect economic growth in North Sumatra.

The exchange rate variable has a coefficient value of minus 0.267515 which is the magnitude of the exchange rate contribution to economic growth in North Sumatra. The regression coefficient of the exchange rate is minus 0.267515 but the probability is significant $(0.0000<0.05)$. This is in accordance with Mundell Fleming's theory (Mankiw, 2007) which states that there is a negative relationship with the exchange rate with economic growth where the higher the exchange rate, the lower net exports will have an impact on the number of outputs which are decreasing and causing economic growth to decline. This is in line with the research conducted by (Bristy, 2014) using the OLS method that the exchange rate effect is significant and negatively to economic growth in Bangladesh.

The unemployment rate variable has a coefficient of minus 0.122176 which is the amount of unemployment contribution to economic growth in North Sumatra. The unemployment regression coefficient is 0.122176 with a negative sign but the probability is significant $(0.0073<0.05)$. The unemployment rate is affects economic growth in North Sumatra. This study is accordance with Okun's Law which states that when the unemployment rate increases, productivity will decrease and the output obtained by the state will also decrease so that economic growth will decrease. And inconsistent research conducted by (Pramesthi, Ekonomi and Surabaya, 2011) using the OLS method to conclude that unemployment effect significantly to economic growth in the County of Trenggalekl

\section{Conclusions}

The amount of money in circulation, the money supply previous period, the interest rate of Bank Indonesia, exchange rate, unemployment and economy together influential significantly 
to inflation in North Sumatra. Meanwhile, partially economic growth effect significantly to inflation in North Sumatra and positive direction. The amount of money in circulation, the money supply previous period a significant and negative effect against inflation in North Sumatra. interest rate of Bank Indonesia, unemployment is a significant and positive effect against inflation in North Sumatra.

Inflation has no effect on the economic growth of North Sumatra. The amount of money in circulation, a significant and positive effect toward economic growth in North Sumatra. While the money supply previous period does not affect economic growth in North Sumatra. The exchange rate effect is significant and negatively to economic growth.

Because the interest rate of Bank Indonesia is a very variable effect on inflation in North Sumatra in both short term and long term, means have been very right Bank Indonesia use interest rates as an instrument of policy monetary. Additionally, the Bank Indonesia should be more focused and be careful in setting the interest rate of Bank Indonesia as the reference interest rate. The need for good cooperation between Bank Indonesia and Government in making policy from the supply and demand sides in achieving the inflation target which is considered good and stable for the economy of North Sumatra.

\section{References}

Amrini, Y., Aimon, H. and Syofyan, E. (2012) 'Analisis Pengaruh Kebijakan Moneter Terhadap Inflasi dan Perekonomian di Indonesia', Buletin Ekonomi Moneter dan Perbankan.

Bristy, H. J. (2014) 'Impact of Financial Development on Exchange Rate Volatility and Long-Run Growth Relationship of Bangladesh', International Journal of Economics and Financial Issues.

Furuoka, F. (2007) 'Does the "Phillips curve" really exist? New empirical evidence from Malaysia', Economics Bulletin.

Hossain, A. A. (2010) 'Monetary targeting for price stability in Bangladesh: How stable is its money demand function and the linkage between money supply growth and inflation?', Journal of Asian Economics. doi: 10.1016/j.asieco.2010.07.003.

Islam, R. et al. (2017) 'Determinants of Factors that Affecting Inflation in Malaysia', International Journal of Economics and Financial Issues.

Mankiw, N. G. (2007) 'Makroekonomi,(Edisi 6)', Jakarta: Erlangga.

Mishkin, F. S. (2015) 'The ISLM Model', in The Economics of Money, Banking, and Financial Markets: Global Edition.

Nazer, Y. (2016) 'Causes of inflation in Saudi Arabia', The Business \& Management Review.

Pahlavani, M. and Rahimi, M. (2009) 'Sources of Inflation in Iran: an Application of the Ardl Approach', International Journal of Applied Econometrics and Quantitative Studies.

Pramesthi, R. N., Ekonomi, F. and Surabaya, K. K. (2011) 'Pengaruh Pengangguran Dan Inflasi Terhadap Pertumbuhan Ekonomi Di Sumatera Utara', Jurnal Ekonomi Studi Pembangunan.

Rahardja, P. and Manurung, M. (2004) 'Teori Ekonomi Makro: Suatu Pengantar', Edisi ketiga. Lembaga Penerbit FE-UI. doi: 10.1146/annurev.ento.48.091801.112645.

Sipayung, P. T. E. and Budhi, M. K. S. (2013) 'Pengaruh PDB, Nilai Tukar dan Jumlah Uang Beredar Terhadap Inflasi di Indonesia Periode 1993-2012', E-Jurnal Ekonomi Pembangunan Universitas Udayana. doi: 10.1016/0014-5793(87)81161-4.

Wisda Nugroho, P. and Umar Basuki, M. (2012) 'ANALISIS FAKTOR-FAKTOR YANG MEMPENGARUHI INFLASI DI INDONESIA PERIODE 2000.1-2011.4’, DIPONEGORO JOURNAL OF ECONOMICS. 